\title{
PENGARUH KECERDASAN SPIRITUAL DAN KOMPETENSI SOSIAL GURU TERHADAP MORAL KERJA GURU DI SD NEGERI KECAMATAN SALO KABUPATEN KAMPAR RIAU
}

\author{
Suharti 1) \\ B. Isyandi 2) \\ Zulkifli. $\mathbf{N}^{3)}$ \\ 1) Post Graduate Student of Riau University \\ 2) Lecturer of Education Management Study Programme PPs University of Riau \\ ${ }^{3)}$ Lecturer of Education Management Study Programme PPs University of Riau
}

\begin{abstract}
This study aimed to analysis and examine the influence of Spiritual Intelligence and Social Competence Master of the Moral Work Elementary School Teacher In Salo District Kampar regency of Riau. The hypothesis this study were: 1). There is a positive influence on Moral Intelligence Spiritual Work with correlation coefficient $=0.316$, the regression equation $Y=86.612+0,015 X 1$. 2). There is a positive influence between Social Competence of the Moral Work with correlation coefficient $=0.411$, the regression equation $Y=45.873+0,444 X 2$. And 3). There is a positive influence between Spiritual Intelligence and Social Competence to Moral Work in the Elementary School Teacher District of Salo, with a correlation coefficient $=0.432$, the regression equation $Y=52.792+0.128 X 1+498 X 2$. Subject research is elementary school teachers District of Salo, a population of 240 people by using simple random sampling (random) then obtained a sample of 150 teachers. Data collection instruments by using questionnaires (questionnaires), to test the hypotheses used to test the validity and reliabelitas. The analysis showed that the Spiritual Intelligence and Social Competence positively affect the Moral Work in the Elementary School Teachers in Salo District of Kampar regency of Riau amounted to $18.7 \%$. Conclusion of the study that there are positive influence between Spiritual Intelligence and Social Competence of the Elementary School Teachers Working Moral In District Salo Kampar regency of Riau.
\end{abstract}

Keywords: Spiritual Intelligence, Social Competence, Moral Work 


\title{
PENGARUH KECERDASAN SPIRITUAL DAN KOMPETENSI SOSIAL GURU TERHADAP MORAL KERJA GURU DI SD NEGERI KECAMATAN SALO KABUPATEN KAMPAR RIAU
}

\begin{abstract}
ABSTRAK
Penelitian ini bertujuan untuk menganalisis dan meneliti pengaruh Kecerdasan Spiritual dan Kompetensi Sosial Guru terhadap Moral Kerja Guru Di SD Negeri Kecamatan Salo Kabupaten Kampar Riau. Hipotesis yang diajukan dalam penelitian ini adalah : 1). Terdapat pengaruh positif Kecerdasan Spiritual terhadap Moral Kerja dengan koefisien korelasi $=0,316$, persamaan regresi $\hat{Y}=86,612+0,015 \mathrm{X}_{1}$. 2). Terdapat pengaruh positif antara Kompetensi Sosial terhadap Moral Kerja dengan koefisien korelasi = 0,411 , persamaan regresi $\hat{Y}=45,873+0,444 X_{2}$. Dan 3 ). Terdapat pengaruh positif antara Kecerdasan Spiritual dan Kompetensi Sosial terhadap Moral Kerja Guru pada SD Negeri Kecamatan Salo, dengan koefisien korelasi $=0,432$, dengan persamaan regresi $\hat{Y}=52,792+0,128 X_{1}+498 X_{2}$. Sabjek penelitian adalah guru-guru SD Negeri SeKecamatan Salo, populasi 240 orang dengan menggunakan simple random sampling (secara acak) maka diperoleh sampel 150 orang guru. Instrumen pengumpulan data dengan menggunakan angket (quisioner), untuk menguji hipotesis digunakan uji validitas dan reliabelitas.Hasil analisis menunjukkan bahwa Kecerdasan Spiritual dan Kompetensi Sosial secara positif berpengaruh terhadap Moral Kerja pada Guru di SD Negeri Kecamatan Salo Kabupaten Kampar Riau adalah sebesar 18,7\%.Kesimpulan penelitian bahwa terdapat pengaruh yang positif antara Kecerdasan Spiritual dan Kompetensi Sosial terhadap Moral Kerja Guru SD Negeri Di Kecamatan Salo Kabupaten Kampar Riau.
\end{abstract}

Kata Kunci: Kecerdasan Spiritual; Kompetensi Sosial; Moral Kerja.

\section{PENDAHULUAN}

Guru mempunyai peran yang sangat besar dalam suatu lembaga pendidikan. Guru merupakan tenaga yang bertanggung jawab dalam terlaksananya kegiatan belajar mengajar. Oleh karena itu guru hendaknya memiliki dedikasi, semangat kerja, tanggung jawab dalam melaksanakan tugasnya, guru sebagai pelaksana pendidikan yang berhubungan langsung dengan peserta didik dan yang berperan besar dalam meningkatkan mutu pendidikan serta menentukan tercapai tidaknya tujuan pendidikan. Artinya guru adalah faktor yang menentukan dalam mencapai tujuan pendidikan di sekolah. Guru yang baik adalah guru yang berkepribadian yang tinggi, yaitu guru yang memandang pendidikan sebagai alat untuk meningkatkan kesejahteraan umat manusia dan mengabdi secara antusias dan penuh tanggung jawab kepada pekerjaannya. Guru harus mampu memberikan pelajaran, tidak hanya memberikan ilmu pengetahuan, tetapi juga mendidik para peserta didik agar menjadi manusia yang berbudi, para pendidik yang seperti ini berarti sudah mampu mengenali dan memahami apa hakikat dari apa yang dilakukannya yaitu menjadi seorang pendidik, panutan bagi orang-orang disekitarnya terutama bagi peserta didiknya dalam menjalankan tugasnya. Dari hasil observasi sementara di Sekolah Dasar Negeri Kecamatan Salo 

$\begin{array}{lrr}\text { Kabupaten } & \text { Kampar Riau gejala } \\ \text { rendahnya } & \text { moral kerja guru, } \\ \text { berdasarkan } & \text { kenyataan dilapangan }\end{array}$ melalui pengamatan penulis terlihat adanya gejala-gejala rendahnya Moral Kerja Guru. Hal itu dapat dilihat dari kebiasaan-kebiasaan yang dilakukan guru seperti masih adanya sebagian guru kurang semangat tidak bergairah sehingga dalam mengajar asal-asalan dalam memberikan materi pelajaran kepada siswa, adanya guru yang pulang kerja sebelum waktunya, masih ada guru yang kurang disiplin dalam menjalankan peraturan disekolah, masih ada guru yang datang terlambat dalam melaksanakan proses belajar mengajar disekolah, masih ada guru yang kurang bertanggungjawab dalam menjalankan tugasnya dan sering meninggalkan jam mengajar untuk menyelesaikan kepentingan pribadi dan bersikap acuh tak acuh terhadap tugasnya, dan adanya guru yang tidak mampu menyelesaikan tugas yang diberikan kepadanya dengan baik seperti tidak piket. Prilaku guru seperti ini mencerminkan prilaku guru yang memiliki moral kerja yang rendah. Hal ini terjadi karena guru tidak mempunyai Kompetensi Sosial dan Kecerdasan Spiritual yang tinggi dalam menjalankan tugasnya.

Sejalan dengan fenomena diatas, Danim menyatakan bahwa "seseorang yang memiliki moral kerja tinggi akan terlihat dari semangat kerjanya, disiplin kerja, partisipasi kerja, dan inisiatif untuk bekerja. Keberhasilan guru dalam melaksanakan tugasnya dipengaruhi oleh banyak faktor salah satunya moral kerja guru dari guru tersebut".

Oleh karena moral kerja merupakan semangat kerja maka moral kerja sangat mempengaruhi produktivitas seseorang. Seorang guru memang harus memiliki moral kerja yang tinggi agar mampu mengajar dengan penuh antusias, kegembiraan dan penuh gairah sehingga menimbulkan daya tarik tersendiri bagi murid-muridnya.Menurut Benge, dalam jurnal Dina Sartika, mengemukakan terdapat tiga faktor yang menentukan terbentuknya moral kerja, yaitu:

a. Aspek Sikap Terhadap Pekerjaan

b. Aspek Sikap Terhadap Atasan

c. Aspek Sikap Terhadap Perusahaan

Guru yang memiliki moral kerja yang tinggi tentu memiliki daya kreativitas dan inisiatif yang tinggi pula dalam memperbaiki kegiatan-kegiatan kependidikan. Sehingga untuk mencapai keberhasilan dalam proses belajar peserta didik dan menciptakan daya kreativitas itu diperlukan suatu kompetensi guru. Kompetensi sosial guru adalah kemampuan seorang guru memahami bahwa dirinya adalah bagian yang tidak dapat dipisahkan dari masyarakat dan warga Negara. Atau lebih dalam lagi kemampuan sosial ini meliputi kemampuan dalam menyesuaikan diri terhadap tuntutan kerja dan lingkungan pada waktu bertugas sebagai guru.Menurut Kunandar bahwa kompetensi guru meliputikompetensi sosial yaitu :

a. Mampu berkomunikasi dan bergaul secara efektif dengan peserta

b. Mampu berkomunikasi dan bergaul secara efektif dengan sesama pendidik dan tenaga kependidikan

c. Mampu berkomunikasi dan bergaul secara efektif dengan orang tua atau wali peserta didik dan masyarakat.

Danah Zohar dan Ian Marshall dalam buku Ari Ginanjar mendefinisikan "Kecerdasan Spiritual sebagai kecerdasan untuk menghadapi berbagai persoalan makna/nilai yaitu kecerdasan untuk menempatkan perilaku dan hidup kita dalam konteks makna yang lebih luas dan kaya, kecerdasan untuk menilai bahwa tindakan atau jalan hidup seseorang lebih bermakna dibanding dengan yang lain". 
Dari pengertian diatas maka kecerdasan spiritual guru dapat diartikan sebagai kemampuan guru dalam mengelola dan mendayagunakan makna-makna, nilai-nilai, dan kualitaskualitas kehidupan spiritualnya, yang meliputi hidup bermakna, yang memotivasi seorang guru untuk senantiasa mencari makna hidup dan mendambakan hidup yang bermakna.

Maka, untuk mewujudkan perubahan pendidikan secara efektif itu, perlu memprioritaskan perencanaan pendidikan yang baik untuk dapat mewujudkan tujuan pendidikan. Dalam hal ini, yang paling berperan aktif adalah guru sebagai tenaga pengajar, mengorganisasikan, menggerakkan dan mengontrol pola pergerakan pendidikan bagi anak didik. Dan untuk itu, seorang guru selain harus memiliki kompetensi sosial dan moral kerja yang tinggi, guru juga perlu memiliki dan mengintegralkan serta menyeimbangkanSpiritual Quotient, agar nantinya dapat melahirkan para generasi yang juga memiliki SQ yang baik.

Ary Ginanjar mengatakan ada tujuh sifat yang harus dijadikan values dan nilai dimana ketujuh sifat itu akan memberikan meaning atau nilai bagi yang melaksanakannya, yang dijadikan indikator pada kecerdasan spiritual yaitu:Jujur,Tanggungjawab,Displin, Kerjasama,Adil, Visioner, dan Peduli.

Apabila kompetensi yang dimiliki pegawai yaitu berupa pengetahuan, keterampilan, sikap dan prilaku kerja yang tinggi maka secara otomatis akan mencerminkan Moral Kerja yang baik dan segala tugas yang dibebankan kepadanya akan dilaksanakan dengan sebaik-baiknya.

Dengan demikian Kecerdasan Spiritual dan Kompetensi Sosial akan mempengaruhi Moral Kerja seseorang (guru), apabila didalam organisasi sekolah guru telah mempunyai sikap yang baik, arif-bijaksana dan didukung dengan kemampuan guru yang kompeten dengan keterampilan dan pengetahuannya yang tinggi, maka diduga Moral Kerja Guru disekolah tersebut akan menjadi baik juga.

Berdasarkan uraian diatas, secara garis besar kerangka berfikir dalam penelitian ini dapat dilihat pada gambar 1 berikut ini:

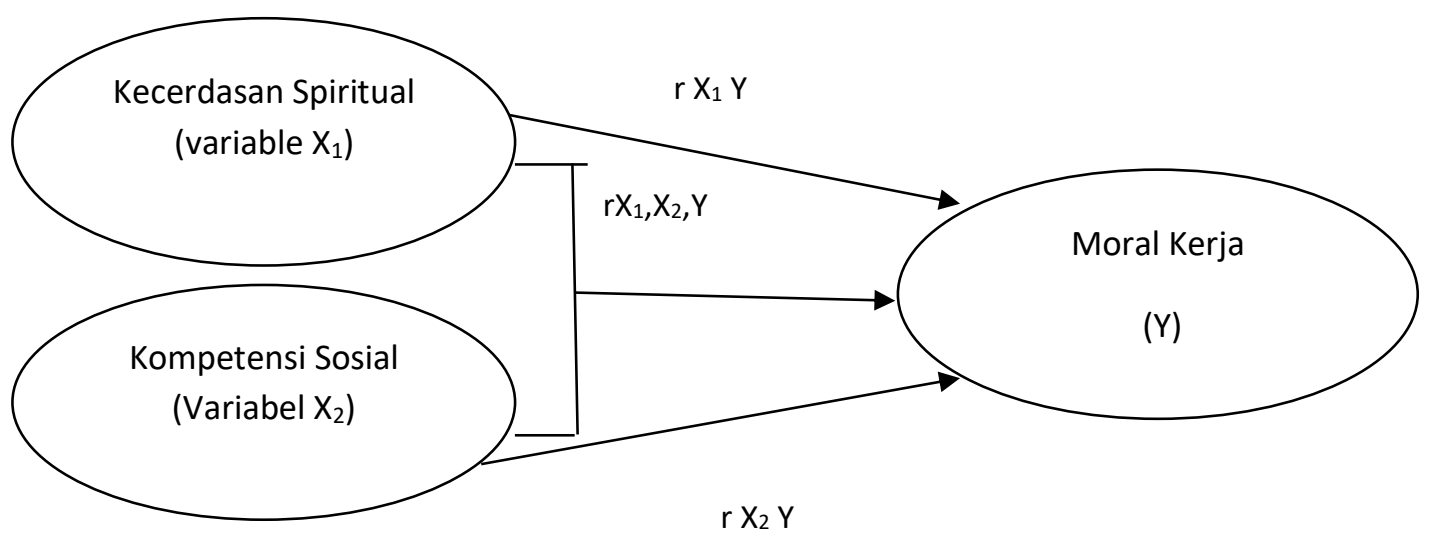

Gambar 1 Konstelasi Masalah

$\mathrm{X}_{1}=$ Kecerdasan SpiritualY $=$ Moral Kerja

$\mathrm{X}_{2}=$ Kompetensi Sosial 
\begin{tabular}{llr}
\multicolumn{4}{c}{ Berdasarkan pada landasan teori } \\
dan kerangka pemikiran diatas, \\
hipotesis yang diajukan dalam \\
penelitian ini adalah kecerdasan \\
spiritual dan kompetensi sosial \\
berpengaruh terhadap moral kerja guru.
\end{tabular}

\section{METODOLOGI PENELITIAN}

Pendekatan penelitian ini menggunakan metode survei deskriptif. Penelitian survey dimaksudkan untuk memperoleh gambaran mengenai moral kerja guru. Penelitian ini dilaksanakan di SD Negeri Se-Kecamatan Salo Kabupaten Kampar Riau. adapun waktu penelitian dilakukan 9 bulan mulai dari Juli 2014 - Maret 2015.

Dalam penelitian ini menggunakan jenis data primer dan data sekunder. Data primer berupa data yang diperoleh dari pihak pertama yang menjadi responden penelitian yang dilakukan melalui penyebaran angket yang mengacu pada variabel kecerdasan spiritual, kompetensi sosial dan moral kerja. Sedangkan data sekunder antara lain kepustakaan dan juga informasi sekolah tersebut. Sumber data dalam penelitian ini adalah guru yang termasuk sebagai sampel penelitian.

Populasi dalam penelitian ini adalah seluruh guru SD Negeri Kecamatan Salo Kabupaten Kampar berjumlah 240 orang. Pada penelitian ini untuk menarik ukuran sampel dari populasi digunakan rumus Yamane dalam Ridwan, yaitu :

Keterangan:

$$
n=\frac{N}{N \cdot d^{2}+1}
$$

$\mathrm{n}=$ ukuran sampel

$\mathrm{N}=$ Ukuran populasi

$\mathrm{d}=$ Presisi yang ditetapkan

Sehingga diperoleh besarnya sampel sebagai berikut:

$$
n=\frac{240}{240 \cdot(0,05)^{2}+1}=\frac{240}{1,6}=150
$$

Setelah ditentukan terdapat 150 responden yang akan dijadikan sampel. untuk menentukan sampel disetiap sekolah yang akan diteliti maka digunakan teknik simple random sampling yaitu pengambilan sampel secara acak supaya setiap elemen dalam populasi mempunyai kesempatan yang sama untuk diseleksi sebagai subjek dalam sampel sehingga diperoleh sampel yang representative dan mampu mewakili populasi.

Pengumpulan data dalam penelitian ini menggunakan angket yang berisikan pernyataan-pernyataan tentang kecerdasan spiritual,kompetensi social, dan moral kerja guru. dengan bentuk angket tertutup yaitu angket yang telah disediakan jawabannya sehingga responden tinggal memilih jawaban yang telah disediakan dengan lima alternaif jawaban yaitu: (1) Selalu, (2) Sering, (3) Kadang-kadang, (4) Jarang, (5) Tidak Pernah.

Dalam penelitian ini untuk melakukan pengujian hipotesis penelitian pengaruh kecerdasan spiritual, kompetensi sosial dan moral kerja guru SD Negeri Di Kecamatan Salo Kabupaten Kampar Riau. Menggunakan regresi berganda dengan bantuan SPSS V. 17. Analisis berganda dalam penelitian ini dapat dinyatakan dalam bentuk regresi berganda dengan rumus :

$$
\begin{gathered}
\hat{\mathbf{Y}}=\mathbf{a}+\mathbf{b}_{1} \mathbf{X}_{\mathbf{1}}+\mathbf{b}_{2} \mathbf{X}_{\mathbf{2}} \\
\text { Keterangan: } \\
\hat{\mathrm{Y}}=\text { Moral Kerja } \\
\mathrm{a}=\text { Konstanta } \\
\mathrm{b}=\text { Pengaruh/koefisian regresi } \\
\mathrm{X}_{1}=\text { Kecerdasan Spiritual } \\
\mathrm{X}_{2}=\text { Kompetensi Sosial }
\end{gathered}
$$


Berikut ini akan dijelaskan definisi konseptual, definisi operasional sebagai berikut :

1. Variabel Moral Kerja

Definisikonseptual moral kerja adalah suatu predisposisi atau kecenderungan untuk menerima atau menolak sesuatu berdasarkan pengalaman dan norma yang dimilikinya yang mempengaruhi kemauan, perasaan dan pikiran untuk bekerja dan berupaya mencapai tujuan yang telah ditetapkan dengan sebaikbaiknya, dengan indikator 1) Sikap Terhadap Pekerjaan,

2) Sikap Terhadap Atasan/rekan, 3) Sikap terhadap organisasi.

Secara operasional Moral kerja adalah suatu predisposisi atau kecenderungan untuk menerima atau menolak sesuatu berdasarkan pengalaman dan norma yang dimilikinya yang mempengaruhi kemauan, perasaan dan pikiran guru untuk bekerja dan berupaya mencapai tujuan yang telah ditetapkan dengan sebaik-baiknya yang tergambar pada perolehan skor melalui angket kepada responden yang diukur dengan indikator sebagai berikut: 1) Sikap Terhadap Pekerjaan, 2) Sikap Terhadap Atasan/Rekan, 3) Sikap terhadap sekolah,terdiri dari 20 pernyataan.

2. Variabel Kecerdasan Spiritual Secara Konseptual Kecerdasan spiritual adalah kecerdasan yang berada dibagian diri yang paling dalam, berhubungan dengan kearifan, penghayatan ketuhanan, menumbuhkan otak dan watak manusia menjadi kreatif, luwes, berwawasan luas dan tabah dalam menghadapi kehidupan, dan SQ merupakan kecerdasan yang tertinggi, dengan indikator 1) Jujur, 2) Tanggungjawab, 3) Disiplin, 4) kerja sama, 5) Adil, 6) Visioner, 7) Peduli.
Secara operasional Kecerdasan spiritual adalah kecerdasan yang berada dibagian diri yang paling dalam yang merupakan kecerdasan yang tertinggi yang dimiliki guru yang tergambar pada perolehan skor melalui angket kepada responden yang diukur dengan indikator sebagai berikut: 1) Jujur, 2) Tanggungjawab, 3) Disiplin, 4) kerja sama, 5) Adil, 6) Visioner, 7) Peduli, terdiri dari 20 pernyataan.

\section{Variabel Kompetensi Sosial}

Definisi konseptual Kompetensi sosial merupakan kemampuan guru untuk berkomunikasi dan bergaul secara efektif dengan peserta didik, sesama pendidik, tenaga kependidikan, orang tua/wali peserta didik, dan masyarakat sekitar. kompetensi sosial guru dilihat dari indikator, 1) Mampu berkomunikasi dan bergaul secara efektif dengan peserta didik, 2) Mampu berkomunikasi dan bergaul secara efektif dengan sesama pendidik dan tenaga kependidikan dan 3) Mampu berkomunikasi dan bergaul secara efektif dengan orang tua/wali peserta didik dan masyarakat sekitar.

Secara operasional Kompetensi sosial merupakan kemampuan guru untuk berkomunikasi dan bergaul secara efektif yang tergambar dengan peserta didik, sesama pendidik, tenaga kependidikan, orang tua/wali peserta didik, dan masyarakat sekitar. kompetensi sosial guru pada perolehan skor melalui angket kepada responden yang diukur dengan indikator sebagai berikut: 1) Mampu berkomunikasi dan bergaul secara efektif dengan peserta didik, 2) Mampu berkomunikasi dan bergaul secara efektif dengan sesama pendidik dan tenaga kependidikan dan 3) Mampu berkomunikasi dan bergaul secara efektif dengan orang tua/wali 
peserta didik dan masyarakat sekitar, terdiri dari 20 pernyataan.

\section{HASIL PENELITIAN DAN PEMBAHASAN}

\section{Deskriptif Data}

Berdasarkan hasil perhitungan terhadap data moral kerja diperoleh skor empiris terendah yang dicapai responden adalah 72 dan skor tertinggi adalah 109. Dengan demikian, rentang skor empiris adalah sebesar 37. Perhitungan terhadap distribusi skor moral kerja menghasilkan: (1) skor mean $=87,97,(2)$ skor median $=88,(3)$ skor modus $=90$ dan (4) skor simpangan baku $=7,609$

Selanjutnya, berdasarkan hasil perhitungan terhadap kecerdasan spiritualdiperoleh skor empiris terendah yang dicapai responden adalah 76 dan skor tertinggi adalah 115. Dengan demikian, rentang skor empiris adalah sebesar 39. Perhitungan terhadap distribusi skor Kecerdasan Spiritual menghasilkan: (1) skor mean $=92,23$ (2) skor median $=90$, (3) skor modus $=$ 90, dan (4) skor simpangan baku = 8,338 .

Dan perhitungan terhadap Kompetensi Sosial diperoleh diperoleh skor empiris terendah yang dicapai responden adalah 83 dan skor tertinggi adalah 122. Dengan demikian, rentang skor empiris adalah sebesar 39. Perhitungan terhadap distribusi skor kompetensi sosial menghasilkan: (1) skor mean $=94,79$ (2) skor median $=$ 94,50 (3) skor modus $=93$, dan (4) skor simpangan baku $=7,045$.

\section{Uji Normalitas}

Uji normalitas data pada penelitian ini menggunakan uji Kolmogorov_smirnov, dengan taraf signifikan yang digunakan sebagai aturan untuk menerima atau menolak pengujian normalitas atau ada tidaknya suatu distribusi data $\alpha=0,05$. Untuk menerima atau menolak hipotesis dengan cara membandingkan nilai signifikan variabel dengan $\alpha=0,05$. Adapun kaidah keputusan, data dinyatakan berdistribusi normal jika nilai signifikan $>\alpha=0,05$.

3. Uji Multikolonearitas Hasil

pengujian multikolonearitas menunjukkan bahwa Kecerdasan Spiritual $\left(\mathrm{X}_{1}\right)$ dan KompetensiSosial masing-masing mempunyai nilai toleransi sebesar 0,883 sedangkan nilai VIF masing-masing sebesar 1,132, maka tidak terdapat gangguan multikolinearitas pada penelitian ini. Sehingga penelitian ini bebas dan layak digunakan. Karena nilai toleransi di bawah 1, dan VIF di atas 1 maka dapat disimpulkan asumsi multikolinearitas terpenuhi yang berarti tidak terdapat hubungan diantara variabel bebas. Sedangkan teknik analisis data yang digunakan dalam penelitian ini adalah regresi berganda.

Tabel 1. . Pengujian Kekuatan Pengaruh Kecerdasan Spiritual dan Kompetensi Sosial terhadap Moral Kerja

\begin{tabular}{|l|l|r|r|r|}
\hline $\begin{array}{l}\text { Mod } \\
\mathrm{el}\end{array}$ & $\mathrm{R}$ & $\begin{array}{c}\mathrm{R} \\
\text { Square }\end{array}$ & $\begin{array}{c}\text { Adjusted } \\
\text { R Square }\end{array}$ & $\begin{array}{c}\text { Std. Error } \\
\text { of the } \\
\text { Estimate }\end{array}$ \\
\hline 1 & $.432^{\mathrm{a}}$ & .187 & .175 & 6.909 \\
\hline
\end{tabular}

a. Predictors: (Constant),

Kompetensi_Sosial, Kecerdasan_Spiritual

b. Dependent Variable: Moral_Kerja

Berdasarkan tabel 1, dapat ditunjukkan dari hasil perhitungan regresi $R$ Square yakni sebesar 0,187. Hal ini menunjukkan bahwa ke dua variabelindependent secara bersamasama mampu memberikan sumbangan terhadap variabel dependent sebesar $18,7 \%$. Semakin tinggi Kecerdasan 
Spiritual dan Kompetensi Sosial maka semakin tinggi Moral Kerjanya.
Selanjutnya, berkenaan dengan persamaan regresi ganda dapat dilihat pada tabel 2.

Tabel 2. Koefisien Regresi Linear Kecerdasan Spiritual dan Kompetensi Sosial terhadap Moral Kerja

\begin{tabular}{|c|c|c|c|c|c|c|}
\hline \multirow{2}{*}{\multicolumn{2}{|c|}{ Model }} & \multicolumn{2}{|c|}{$\begin{array}{l}\text { Unstandardized } \\
\text { Coefficients }\end{array}$} & $\begin{array}{l}\text { Standardized } \\
\text { Coefficients }\end{array}$ & \multirow[b]{2}{*}{$\mathrm{T}$} & \multirow[b]{2}{*}{ Sig. } \\
\hline & & B & Std. Error & Beta & & \\
\hline \multirow[t]{3}{*}{1} & (Constant) & 52.792 & 8.573 & & 6.158 & .000 \\
\hline & $\begin{array}{l}\text { KecerdasanS } \\
\text { piritual }\end{array}$ & .128 & .072 & .141 & 1.777 & .078 \\
\hline & $\begin{array}{l}\text { Kompetensi_ } \\
\text { Sosial }\end{array}$ & .496 & .085 & .459 & 5.802 & .000 \\
\hline
\end{tabular}

a. Dependent Variable: Moral_Kerja

Dari tabel 2. Kecerdasan Spiritual $\left(\mathrm{X}_{1}\right)$ dan kompetensi sosial $\left(\mathrm{X}_{2}\right)$ secara bersama-sama terhadap
Moral Kerja (Y) yang dapat disusun regresi yaitu $\hat{Y}=52,792+0,128 X_{1}+496 X_{2}$

Tabel 3.Koefisien Korelasi Ganda Pengaruh Kecerdasan Spiritual dan Kompetensi Sosial terhadap Moral Kerja

\begin{tabular}{|c|c|c|}
\hline No & Perhitungan & Hasil \\
\hline 1 & Korelasi $(\mathrm{r})$ & 0,432 \\
\hline 2 & Determinasi $\left(\mathrm{r}^{2}\right)$ & 0,187 \\
\hline
\end{tabular}

Dari tabel 3. Koefisien determinasi $0,432^{2}=0,187$ atau $18,7 \%$. Ini berarti bahwa $18,7 \%$ variasi variabel Moral Kerja dalam persamaan regresi ganda dapat dijelaskan oleh Kecerdasan Spiritual dan Kompetensi Sosial bersama-sama melalui persamaan regresi.

$\hat{\mathbf{Y}}=\mathbf{a}+\mathbf{b}_{1} \mathbf{X}_{1}+\mathbf{b}_{2} \mathbf{X}_{2}$

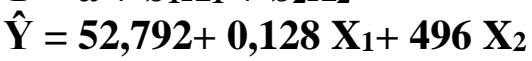

Interpretasi dari regresi di atas adalah sebagai berikut:

a. Konstanta (a) = 52,792 artinya jika Kecerdasan Spiritual dan KompetensiSosial di obyek penelitian sama dengan nol (0), maka MoralKerja (Y) sebesar 52,792 .

b. Koefisien regresi $\left(b_{1}\right)=0,128$ dan bertanda positif, artinya jika variabel Kecerdasan Spiritual naik satu satuan, maka terjadi kenaikan terhadap Y sebesar 0,128 (variabel MoralKerja naik sebesar 0,128).

c. Koefisien regresi $\left(b_{2}\right)=0,498$ dan bertanda positif, artinya jika variabel KompetensiSosial naik satu satuan, maka terjadi kenaikan terhadap Y sebesar 0,498 (variabel MoralKerja naik sebesar 0,498).

Pengujian signifikan dan linearitas persamaan regresi dapat dilihat pada tabel 4. 
Tabel 4. Nilai F hitung Kecerdasan Spiritual dan Kompetensi Sosial terhadap Moral Kerja

\begin{tabular}{|c|c|c|c|c|c|c|}
\hline \multicolumn{2}{|c|}{ Model } & $\begin{array}{l}\text { Sum of } \\
\text { Squares }\end{array}$ & Df & Mean Square & $\mathrm{F}$ & Sig. \\
\hline \multirow[t]{3}{*}{1} & Regression & 1609.266 & 2 & 804.633 & 16.857 & $.000^{\mathrm{a}}$ \\
\hline & Residual & 7016.627 & 147 & 47.732 & & \\
\hline & Total & 8625.893 & 149 & & & \\
\hline
\end{tabular}

Berdasarkan tabel 4. Diperoleh $\mathrm{F}$ hitung sebesar 16,857 dengan signifikan 0,000 atau pada taraf $5 \%$ dengan df $\mathrm{n}-2$ $=148$ diperoleh $\mathrm{F}$ tabel $=3,06$. Maka $\mathrm{F}$ hitung 16,857> $\mathrm{F}$ tabel 3,06, jadi Ho ditolak dan Ha diterima yang artinya Kecerdasan Spiritual dan KompetensiSosial secara bersama-sama berpengaruh positif terhadap MoralKerja pada Guru SD Negeri di Kecamatan Salo Kabupaten Kampar.

b. Hipotesis kedua yang akan diuji adalah

Tabel 5 Koefisien Regresi Linear $\mathrm{X}_{1}$ terhadap Y. terdapat pengaruh antara variabel bebas terhadap variabel terikat dengan menggunakan uji $\mathrm{t}$ dengan kriteria :

1.Jika $\mathrm{t}$ hitung $>$ dari $\mathrm{t}$ tabel, maka Ho ditolak dan Ha diterima, artinya ada pengaruh signifikan antara variabel bebas terhadap variabel terikat.

2.Jika $\mathrm{t}$ hitung $<$ dari $\mathrm{t}$ tabel, maka Ho diterima dan $\mathrm{Ha}$ ditolak, yang artinya tidak ada pengaruhantara variabel bebas terhadap variabel terikat.

\begin{tabular}{|c|c|c|c|c|c|}
\hline \multirow[b]{2}{*}{ Model } & \multicolumn{2}{|c|}{$\begin{array}{l}\text { Unstandardized } \\
\text { Coefficients }\end{array}$} & \multirow{2}{*}{\begin{tabular}{|l}
$\begin{array}{l}\text { Standardized } \\
\text { Coefficients }\end{array}$ \\
Beta
\end{tabular}} & \multirow[b]{2}{*}{$\mathrm{t}$} & \multirow[b]{2}{*}{ Sig. } \\
\hline & $B$ & Std. Error & & & \\
\hline $1 \quad$ (Constant) & 86.612 & 6.945 & & 12.471 & .000 \\
\hline $\begin{array}{l}\text { Kecerdasan } \\
\text { Spiritual }\end{array}$ & .015 & .075 & .016 & .197 & .844 \\
\hline
\end{tabular}

a. Dependent Variable: Moral_Kerja

Bahwa nilai $\mathrm{t}$ hitung $=12,471$, diketahui $\mathrm{n}=150$ maka $\mathrm{df}=\mathrm{n}-\mathrm{k}, 150-$ $2=148$. Dibandingkan dengan nilai $\mathrm{t}$ tabel pada $\mathrm{df}=148$ dengan taraf signifikan 5\% maka di dapat nilai $t$ tabel $=1,960$. Kemudian dibandingkan antara $\mathrm{t}$ tabel dengan $\mathrm{t}$ hitung di dapat $\mathrm{t}$ hitung $(12,471)>t$ tabel $(1,960)$. Dengan demikian karena $t$ hitung $>t$ tabel maka Ho ditolak dan $\mathrm{Ha}$ diterima, maka ada pengaruh Kecerdasan Spiritual terhadap
MoralKerja Guru SD Negeri Di Kecamatan Salo Kabupaten Kampar.

\section{c. Pengaruh Kompetensi Sosial $\left(\mathbf{X}_{2}\right)$ terhadap Moral Kerja (Y)}

Hipotesis ketiga yang akan diuji adalah "Terdapat pengaruh positif dan signifikan Kompetensi Sosial $\left(\mathrm{X}_{2}\right)$ terhadap Moral Kerja (Y)", dengan menggunakan uji t dengan kriteria: 
1.Jika $\mathrm{t}$ hitung $>$ dari $\mathrm{t}$ tabel, maka Ho ditolak dan Ha diterima, artinya ada pengaruh signifikan antara variabel bebas terhadap variabel terikat.
2.Jika $\mathrm{t}$ hitung $<$ dari $\mathrm{t}$ tabel, maka $\mathrm{Ho}$ diterima dan Ha ditolak, yang artinya tidak ada pengaruh antara variabel bebas terhadap variabel terikat.

Tabel 6. Koefisien Regresi Linear Kompetensi Sosial $\left(\mathrm{X}_{2}\right)$ terhadap Moral Kerja (Y)

\begin{tabular}{|c|c|c|c|c|c|c|}
\hline \multirow{2}{*}{\multicolumn{2}{|c|}{ Model }} & \multicolumn{2}{|c|}{$\begin{array}{c}\text { Unstandardized } \\
\text { Coefficients }\end{array}$} & \multirow{2}{*}{$\begin{array}{c}\text { Standardized } \\
\text { Coefficients } \\
\text { Beta }\end{array}$} & \multirow[b]{2}{*}{$\mathrm{t}$} & \multirow[b]{2}{*}{ Sig. } \\
\hline & & B & Std. Error & & & \\
\hline 1 & (Constant) & 45.873 & 7.692 & & 5.963 & .000 \\
\hline & $\begin{array}{l}\text { Kompetensi } \\
\text { Sosial }\end{array}$ & .444 & .081 & .411 & 5.488 & .000 \\
\hline
\end{tabular}

a. Dependent Variable: Moral_Kerja

Dari tabel 5. Dapat dilihat nilai $\mathrm{t}$ hitung $=5,963$ diketahui $\mathrm{n}=150$ maka $\mathrm{df}=\mathrm{n}-\mathrm{k}, 150-2=148$. Dibandingkan dengan nilai $\mathrm{t}$ tabel pada $\mathrm{df}=148$ dengan taraf signifikan 5\% maka di dapat nilai t tabel $=1,960$. Kemudian dibandingkan antara $t_{\text {tabel }}$ dengan $t_{\text {hitung di dapat } t}$ hitung $(5,963)>t$ tabel $(1,960)$. Dengan demikian karena $t$ hitung $>t$ tabel maka Ho ditolak dan $\mathrm{Ha}$ diterima, maka ada pengaruh KompetensiSosial terhadap MoralKerja Guru SD Negeri Di Kecamatan Salo Kabupaten Kampar.

6. Keterbatasan Penelitian

Meskipun peneliti sudah berusaha untuk mengurangi keterbatasan-keterbatasan dalam penelitian ini, namun masih ada terdapat keterbatasan dalam penelitian ini, namun tidak mengurangi tingkat signifikan dalam penelitian.

Keterbatasan-keterbatasan dalam penelitian ini antara lain: 1) Responden yang menjadi objek penelitian mamiliki karakter yang berbeda-beda sehingga sulit untuk mendekati kenyataan yang sebenarnya sehingga mempengaruhi analisis penelitian ini; 2) Dalam mengerjakan angket responden merasa tidak berkepentingan terhadap penelitian, sehingga responden kurang sungguhsungguh dalam mengisi angket; dan 3)Karena selain jumlah responden yang besar, juga responden tersebar di daerah pada radius yang berjauhan, maka timbul keterbatasan waktu, tenaga dan biaya.

\section{SIMPULAN， IMPLIKASI DAN SARAN}

1. Simpulan

Berdasarkan hasil pengujian hipotesis dan penelitian yang dilakukan, maka dapat diambilbeberapa kesimpulan :

1. Terdapat pengaruh yang positif antara Kecerdasan Spiritual terhadap Moral Kerja Guru SD. Negeri Di kecamatan Salo Kabupaten Kampar. Hasil analisis data diperoleh bahwa Kecerdasan Spiritual memberi kontribusi yang signifikan terhadap Moral Kerja Guru sebesar $9,9 \%$.

2. Terdapat pengaruh yang positif antara Kompetensi Sosial terhadap Moral Kerja 
Guru SD. Negeri Di Kecamatan Salo Kabupaten Kampar. Hasil pengolahan analisis data menunjukkan bahwa pengaruh Kompetensi Sosial memberikan kontribusi yang signifikan terhadap Moral Kerja Guru sebesar $16,9 \%$.

3. Terdapat pengaruh yang positif antara Kecerdasan Spiritual dan Kompetensi Sosial terhadap Moral Kerja Guru SD. Negeri Di Kecamatan Salo Kabupaten Kampar. Besarnya pengaruh Kecerdasan Spiritual dan Kompetensi Sosial terhadap Moral Kerja Guru SD. Negeri Di Kecamatan Salo Kabupaten Kampar sebesar $18,7 \%$.

\section{Implikasi Penelitian}

Implikasi hasil penelitian pada masalah Kecerdasan Spiritual dan Kompetensi Sosial ternyata berpengaruh pada Moral Kerja Guru. Berikut ini akan dikemukakan beberapa upaya peningkatan tersebut yaitu : Pertama, menciptakan upaya-upaya untuk memotivasi Kecerdasan Spiritual, Kompetensi Guru, dan Moral kerja melalui fasilitas -fasilitas yang disediakan sekolah. Kedua, menciptakan aturan yang dapat meningkatkan Kecerdasan Spiritual, Kompetensi Sosial Guru dan Moral Kerja Guru, dengan cara kepala sekolah memberikan pengayaan kepada guru yang bertujuan untuk memotivasi kinerja guru, memberikan penghargaan kepada guru yang berprestasi dengan tujuan meningkatkan Moral Kerja Guru, meningkatkan hubungan kekeluargaan dalam organisasi. Ketiga, menciptakan birokrasi yang peduli pada kesulitan guru dan melakukan pembinaan yang dapat meningkatkan kesejahteraan guru secara psikologis.

3. Saran

Berdasarkan hasil kesimpulan dan implikasi, maka saran yang diberikan adalah :

1. Bagi guru, dapatmeningkatkan kreatifitas dan menetapkan target baru yang dapat dilakukan hari ini, disesuaikan dengan keadaan dan kemampuan guru, guru selalu melakukan introspeksi terhadap motivasi dan filosofi menjadi guru, guru selalu yakin dengan keberhasilannya dalam melaksanakan tugas dan mendapatkan penghargaan atau reward.

2. Kepala Sekolah sebagai berikut: memberikan pengayaan pekerjaan yang bertujuan untuk meningkatkan motivasi, kepuasan dan kinerja guru, memberikan penghargaan atau reward kepada guru-guru yang berprestasi dengan tujuan untuk meningkatkan kompetensi sosial dan motivasi dalam menjalankan profesinya sebagai guru, meningkatkan kegiatan informal berupa pertemuan social atau kekeluargaan.

3. Kepada Departemen Pendidikan Nasional khususnya diwilayah Kabupaten Kampar, dengan cara menciptakan birokrasi yang peduli pada kesulitan guru dan memprogramkan menambah kecerdasan guru melalui seminar, yang dapat meningkatkan kesejahteraan guru secara psikologis. 


\section{DAFTAR PUSTAKA}

Abdul Wahab,dkk.,

(2011), Kepemimpinan dan Kecerdasan Spiritual, Ar Ruzz Media, Jakarta.

Agus Efendi., (2005), Revolusi Kecerdasan Abad 21, Bandung.

Alderfer., (2009), Pembinaan Moral Kerja Guru Sekolah Dasar, diakses 10 Mei 2011.

Ary Ginanjar Agustian., (2001), Rahasia Sukses Membangun Kecerdasan Emosi dan Spiritual ESQ, Arga, Jakarta.

Dina Sartika., (2007), Peran Moral Kerja, dalam jurnal Meningkatkan Produktivitas Karyawan, Universitas Bandung, Bandung.

Firdaus Abdillah., dalam jurnal Kompetensi Sosial Guru.

Hamzah.B.Uno., (2007), Teori Motivasi dan Pengukuran Analisis Dibidang Pendidikan, Bumi Aksara, Jakarta.

Ibrahim Bapadal., (2004), Peningkatan Profesionalisme Guru Sekolah Dasar, PT. Bumi Aksara, Jakarta.

Iswahyudi., (2009), Pengaruh Kompetensi Manajerial, dalam jurnal Kinerja Pimpinan, Universitas Islam Indonesia, Jakarta.

Karmila., (2009), Kecerdasan Spiritual dengan Pendidikan Karakter Di SD. Negeri, Universitas Negeri Malang, Malang.

Kunandar., (2010), Guru Profesional, PT. Raja Grafindo Persada, Jakarta.
Masnur Muslich., (2008), KTSP Pembelajaran Berbasis Kompetensi dan Kontekstual, Bumi Aksara, Jakarta.

Mulyasa., (2007), Standar Kompetensi Guru dan Sertifikasi Guru, Rosdakarya, Bandung.

Riduwan., (2005), Belajar Mudah Penelitian Untuk Guru, Karyawan, dan Peneliti Pemula, Alfabeta, Bandung.

Sardiman., (2004), Interaksi dan MotivasiBelajar Mengajar, Raja Grafindo Persada, Jakarta.

Siswanto Sastrohadiwiryo., (2005), Manajemen Tenaga Kerja Indonesia Pendekatan Administratif dan Operasional, Bumi Aksara, Jakarta.

Sonya Sofiana., (2011), Moral Kerja Guru Dalam Mengajar Di SD. Negeri, Universitas Negeri Padang, Padang.

Sudarwan Danim., (2003), Motivasi Administrasi Manajemen dan Kepemimpinan Pendidikan, Bumi Aksara, Jakarta. 